\title{
La filosofía como curación por la palabra
}

\author{
Philosophy as a cure through the word
}

\author{
PABLO GARCÍA CASTILLO \\ Universidad de Salamanca
}

Recibido: 06-12-2018 Aceptado: 14-12-2018

\begin{abstract}
RESUMEN
La sociedad griega fue una sociedad oral. La palabra fue el medio de la educación y de la convivencia política de los griegos. Desde Homero y Pitágoras hasta Empédocles, Gorgias y Sócrates, la palabra se convierte en el fármaco de las enfermedades de la ciudad y del alma. Por ello, puede constatarse que la filosofía es entendida en la Grecia antigua como medicina y que ésta es la metáfora más elocuente del poder y la eficacia de la palabra del filósofo.
\end{abstract}

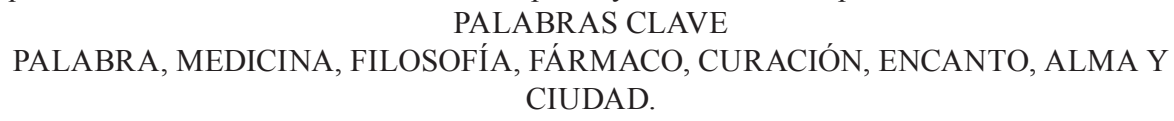

\section{ABSTRACT}

Greek society was an oral one. Word was the way for Greek policy education and cohabitation. From Homer and Pythagoras to Empedocles, Gorgias and Socrates, word becomes the city and soul diseases drug. Therefore, it can be verified that philosophy is understood in ancient Greece as medicine and this is the most eloquent metaphor of power and effectiveness in philosopher word.

\section{KEYWORDS}

WORD, MEDICINE, PHILOSOPHY, DRUG, CURE, SPELL, SOUL, CITY 
MuCHO ANTES DE QUE LOS PRIMEROS HOMBRES INTELIGENTES inventaran esta sorprendente pintura de los sonidos que son las letras de la escritura, ya existía la palabra como vehículo de comunicación. Así que ya en el principio fue y era la palabra, como dijo en el inicio de su Prólogo San Juan, ${ }^{1}$ aunque, tal vez sin saberlo, no hacía más que glosar, a más de seiscientos años de distancia, las primeras proposiciones de la enigmática obra de Heráclito, la cual, según la opinión de los expertos, comenzaba en estos términos:

Aunque esta palabra existe siempre, los hombres son incapaces de comprenderla, tanto antes de haberla oído, como después de haberla oído. En efecto, aunque todas las cosas acontecen según esta palabra, los hombres parecen no tener experiencia de ella. ${ }^{2}$

La palabra fue, según Heráclito, no sólo al principio, sino el principio (arkhé) del cosmos y del hombre, la razón y el sentido de la physis y el oro escondido en la profundidad insondable del alma, cuyos límites nunca podrán encontrarse, pues la tarea de conocerse a sí mismo y pensar sabiamente es interminable. ${ }^{3}$

Pero, al principio, fue la palabra que se escucha, la que vive en el tiempo antes de que fuera dibujada en el espacio de la tablilla o de la página en blanco. Pues habrían de transcurrir siglos hasta que unos griegos, de fino oído y ojos despiertos, lograran reproducir con la fidelidad que es posible los sonidos significativos de la voz humana. Sin embargo, antes de que la lectura y la escritura se convirtieran en los primeros pasos del aprendizaje infantil, el lenguaje oral fue la base de la educación de los griegos, pues en esa forma auditiva de la oralidad se fijaron en la memoria y fueron transmitidos los mitos, los primeros relatos de la cultura occidental. Mas los mitos están hechos de palabras, antes que de hechos; son pura narración carente de referencia y de verificación, pues los dioses, los héroes y sus hazañas fueron una hermosa construcción de palabras (poíesis), que rodaron a través de numerosas generaciones para convertirse en la primera y fundamental forma de paideía.

Por eso, cabe afirmar que, antes que el mito, fue el logos, la palabra con sentido y significado comprensible y comunicable, la trama de todo relato, la fuente de

1 «Al principio era la Palabra, y la Palabra estaba en Dios, y la Palabra era Dios. Todas las cosas fueron hechas por Ella, y sin Ella no se hizo nada de cuanto ha sido hecho (Jn 1, 1-3).

2 DK 22 B 1.

3 Esto es lo que podemos leer en algunos de los más profundos aforismos de Heráclito, como cuando dice. «Nunca encontrarás los límites del alma por mucho que la recorras caminando, tan insondable es su Logos» (DK 22 B 45). O tal vez: «Lo propio de la naturaleza es ocultarse» (DK 22 B 123). O también: «una sola cosa es la sabiduría: conocer el logos que lo gobierna todo a través de todo» (DK $22 \mathrm{~B} 41$ ). Y finalmente: «Al alma pertenece el logos que se acrecienta por sí mismo» (DB $22 \mathrm{~B} 115$ ). 
toda narración digna de ser contada y recordada. Sin la palabra humana hubieran desaparecido los sueños y la experiencia de nuestros antepasados, aquellos griegos que inventaron, gracias a su inigualable capacidad de contar lo imaginado y a su singular alfabeto, el universo de los mitos que pueblan nuestra fantasía y nuestra forma de pensar y de vivir, aunque no seamos del todo conscientes de ello.

Los poemas de Homero constituyen el libro de texto de la educación ateniense y griega. Un libro de texto «oral», que se aprende y se conserva en la memoria, porque incluye toda la enciclopedia de las ciencias griegas, los usos y costumbres, las técnicas de construcción de naves y de estrategia militar y, sobre todo, las normas de la excelencia ética, los modelos de vida que los griegos no sólo habían de memorizar, sino reproducir en la vida cotidiana, mediante un proceso de mímesis, de identificación de su alma con la de los héroes homéricos o con los protagonistas de las tragedias. Por eso critica Platón, en el Fedro, ${ }^{4}$ esta forma de oralidad mimética que produce una enfermedad del alma, que sólo la medicina, el phármakon de la oralidad dialéctica de Sócrates puede curar.

Antes de Homero ya la palabra ejerció el poder medicinal que aparece en sus versos, pero con ellos comienza una trasformación de su poder, que va desde la magia de los ensalmos a la terapia curativa del alma y de la polis en el diálogo socrático, en el que el reino de la palabra mágico-religiosa será ocupado por el imperio de la palabra dialogada.

En este sentido, hay que resaltar la importancia decisiva que tuvo la palabra oral en la configuración de la cultura griega, poniendo de manifiesto la perfecta adecuación de la analogía entre medicina y filosofía que llega a su culminación en el diálogo socrático. Creo que la metáfora más genuina de la filosofía es la que convierte al filósofo en médico del alma y de la polis.

El profundo y minucioso análisis del profesor Laín Entralgo sobre la curación por la palabra en Grecia, ${ }^{5}$ que me ha servido de guía, muestra con claridad que, en los versos épicos, pueden distinguirse cuatro modos distintos de concebir la enfermedad: el traumático, el punitivo, el ambiental y el demoníaco. ${ }^{6}$ Es fácil suponer que las enfermedades traumáticas son las más frecuentes en los poemas homéricos, pues en ellos se narran acciones violentas y travesías arriesgadas. Alguna vez los dioses envían a los hombres enfermedades, como la peste que Apolo lanza sobre los aqueos para castigar el rapto de la hija de Crises por Agamenón (Il. I, 8 ss.) y, en alguna ocasión, también el frío, como causa ambiental, puede hacer enfermar a Ulises ( $O d$. V, 453 ss.) o a Héctor (Il. VI, 264-265). Muy rara vez, sin embargo, se produce una posesión demoníaca

4 Platón, Fedro, 274 b - 278 e.

5 Laín, P., La curación por la palabra en la antigüedad clásica, Barcelona, Anthropos, 2005.

6 Ib. 16. 
que trastorna y consume a un mortal, pero, al menos en una ocasión, la sufrió Ulises, que estuvo cabalgando sobre una tabla, tras su naufragio, vagando por el mar a merced de las olas (Od. V, 394-398).

De entre todos los tratamientos que reciben estos cuatro tipos de enfermedades, destaca una terapéutica, asociada al uso de la palabra, que recibe el nombre de epaoidé y, más tarde, epodé. Es la curación por medio de la palabra que nace a la historia en este pasaje homérico:

Mas los hijos de Autólico, al verlo, acercáronse a Ulises, el igual a los dioses, curaron la herida, vendaron diestramente la pierna, con un ensalmo cortaron el flujo de la sangre y volvieron aprisa a la casa paterna. ${ }^{7}$

Aunque éste es el primer testimonio escrito del ensalmo o conjuro (epaoidé, epodé), según afirma Laín Entralgo,

el empleo de ensalmos o conjuros con intención terapéutica - fórmulas verbales de carácter mágico, recitadas o cantadas ante el enfermo para conseguir su curación - pertenece, acaso desde el paleolítico, a casi todas las formas de la cultura llamada 'primitiva'. Parece inexcusable pensar, en consecuencia, que la epaoidé de los hijos de Autólico es el testimonio literario de una tradición mucho más arcaica... Desde esos remotos orígenes hasta los últimos años de su período helenístico, nunca la epodé mágica perderá su vigencia en la medicina popular de la Hélade. ${ }^{8}$

La palabra griega epodé, que los latinos tradujeron literalmente como incantum o incantamentum, es el ensalmo, el encanto, el poder curativo que encierra la palabra unida a la música. Su poder es tal que puede liberar al enfermo de una posesión demoníaca, puede aplacar las «potencias» divinas que pueblan el cosmos y castigan a los mortales por sus actos impíos o injustos. En una sociedad que entiende la naturaleza (physis) como el conjunto de los seres que nacen y mueren, sometidos a una regularidad implacable, y aquejados de una fragilidad que los lleva a la muerte con rapidez, es fácil presentir a los dioses tras la enfermedad. Por ello, como señala Laín Entralgo:

Bajo una forma u otra, el ensalmo griego pretendía el logro mágico de cuanto el hombre necesita y no puede alcanzar mediante sus recursos naturales: tiempo favorable, amor a voluntad, obediencia automática a otra persona, alteración preternatural del cosmos, curación de la enfermedad. Bajo la presión del ensalmo, las

7 Homero, Odisea, XIX, 455-458.

8 Laín, P., La curación ..., cit., pp. 29-30. 
potencias superiores al hombre - dioses con nombre propio o daímones oscuros e innominados - se plegarían al deseo del ensalmador o de quienes creyentemente han recurrido a él. ${ }^{9}$

En el fondo de esta creencia en el poder mágico de la palabra se halla una concepción religiosa de la propia naturaleza, habitada por innumerables potencias divinas. Sagrados eran los dioses, a los que los hombres recurrían con frecuencia suplicando una señal de protección. Mas los hombres mismos, a pesar de no poseer la inmortalidad, no por ello dejaban de ser divinos, sagrados. Sagrado era el alimento y la naturaleza en general. Todo era sagrado. La Naturaleza y la divinidad se hallaban entrelazadas. El mundo era naturalmente sagrado.

El ensalmo fue ganando cada vez más presencia en todas las manifestaciones de la cultura griega. Así, cabe entender como ensalmos los himnos órficos, el culto dionisíaco, la mántica de Delfos y algunos versos de los poemas épicos.

Los himnos órficos son algo más que canciones rituales, cuya música produce un efecto catártico. La fama de Orfeo como gran cantor, representado en copas y ánforas amansando las fieras con el tañido de su lira, no se basa en su música, sino en los poemas que declamaba, acompañándose con la lira. La fórmula eficaz de los encantamientos mágicos de Orfeo fue el ensalmo, la epodé, en el sentido más literal y etimológico de la palabra: epodé, incantamentum. Son fórmulas mágicas, cantadas y recitadas, que más tarde pasarán a la escritura y se convertirán en una especie de amuleto contra la enfermedad.

Algo semejante sucede entre los pitagóricos, los cuales llegaron a establecer, en palabras de Luis Gil, «una especie de farmacopea musical» ${ }^{10}$ para los distintos tipos de pasiones y momentos del día. Y, como comprobamos en distintos pasajes de la Vida de Pitágoras de Jámblico,

empleaban también para ciertas enfermedades los encantos y creían que la música contribuía grandemente a la salud, si se la empleaba del modo más conveniente (Vit. Pyth. 29).

De ello se deduce que, como en los himnos órficos, no siempre se servían sólo de música, sino que ésta era acompañada en ocasiones de ensalmos o fórmulas rítmicas, que producían un efecto catártico y armónico en el alma afectada por pasiones desordenadas.

También los ritos orgiásticos del culto a Dioniso tuvieron, a los ojos helénicos, una fuerte virtud curativa. Dioniso es considerado el Liberador (Lysios),

$9 \quad I b .64-65$.

10 Gil, L., Therapeia. La medicina popular en el mundo clásico, Madrid, Triacestela, 2004, p. 306. 
pues él, tras escuchar las palabras de súplica de sus devotos, libera de la locura y del delirio báquico. Mediante el enthousiasmós de la orgía ritual curaba a sus fieles de la locura y de toda enfermedad y, por ello, Eurípides (Bacantes, 234) le da el nombre de epodós o ensalmador, aunque curaba, más que por las palabras, por el ritmo frenético de la música y las danzas delirantes de los poseídos por el entusiasmo.

Orales fueron, en cambio, los oráculos de Delfos y los del culto apolíneo. Apolo es también un dios sanador, aunque cede ese papel a su hijo Asclepio. El oráculo de Apolo es la fórmula verbal que produce la salud y libra de la enfermedad, como en el caso de la peste de Tebas, en que Edipo manda a Delfos a su cuñado Creonte con el fin de que éste «aprenda lo que él, Edipo, debe hacer o decir para salvar a la ciudad»». ${ }^{11} \mathrm{Y}$ el mismo Platón, al referirse al segundo tipo de locura (manía) divina, es decir, la locura profética, recoge esta tradición que atribuye a los oráculos inspirados ese poder curativo, cuando afirma que

en sus arrebatos de locura la profetisa de Delfos y las sacerdotisas de Dodona obraron muchos beneficios, públicos y privados, para Grecia. Incluso de las enfermedades y pruebas más horribles que, a consecuencia de faltas antiguas, y sin que se sepa de dónde vienen, afligen a algunas familias, encontró la locura profética una liberación. ${ }^{12}$

También hay un cierto ensalmo en la poesía de Homero. En estos momentos de la prehistoria de la palabra curativa, anteriores al uso racional y filosófico del logos, se da una unión del hombre con lo divino, que se mantendrá hasta el tiempo de Sócrates. La presencia de la epodé en los poemas homéricos, que supone una larga tradición oral que la ha conservado, demuestra esa capacidad de la palabra humana para entrar en contacto con las fuerzas divinas que pueblan la naturaleza. Pero es un poder que viene de dioses, como Apolo, que procuró que llegara a los mortales por medio de héroes y médicos instruidos por la divinidad. Es el caso de Asclepio, que tiene una presencia destacada en los relatos épicos y que se convertirá, con el paso del tiempo, en el dios de la salud, a pesar de que Homero jamás le llame dios. Píndaro, que es el primero en usar el término epaoidé, tras Homero, relata cómo Quirón, el centauro, adiestró a Asclepio en el uso terapéutico del ensalmo:

¿No es él - Quirón -, el que antaño instruyó al dulce artesano de la salud robusta, Asclepio, héroe sanador de todas las enfermedades...? Apolo le llevó al Centauro de Magnesia y se lo confió para que le enseñase a curar las aflictivas enfermedades de los hombres. A todos los que vienen a él portadores de úlceras nacidas

11 Sófocles, Edipo Rey, 69-72.

12 Platón, Fedro 244 a-e.

Contrastes vol. XXIII-N³ (2018) 
en su carne, heridos en alguna parte por el bronce reluciente o por la piedra de la honda, maltratado el cuerpo por el ardor del estío o por el frío del invierno, les libra del mal, ya curándoles con suaves ensalmos (malakais epaoidaís), ya administrándoles pociones benéficas, ya aplicando a sus miembros toda clase de remedios, ya, en fin, poniéndoles en pie mediante incisiones. ${ }^{13}$

Este texto de Píndaro nos revela algo singular. Mientras en los versos homéricos el ensalmo es practicado por cualquier mortal, sin preparación específica alguna, que, enfrentado a una situación de emergencia, pronunciaba unas palabras mágicas que producían un efecto sanador inmediato, Píndaro nos dice lo contrario. Apolo, divinidad protectora de las artes médicas, lleva a su hijo Asclepio al centauro Quirón con el fin de que aprenda los secretos del arte de curar enfermedades. Y, entre las diversas modalidades de tratamientos aprende el arte de los ensalmos, que será heredado por los médicos griegos, naciendo así la logoterapia, es decir, la curación por la palabra. El médico será el experto que sabe cuándo ha de utilizar el phármakon de la palabra y cuándo está contraindicado su uso por requerir la curación del enfermo un tratamiento más expeditivo. Así lo leemos en una tragedia de Sófocles:

No es propio de un médico sabio entonar ensalmos ante una dolencia que exige una intervención quirúrgica. ${ }^{14}$

Fue Platón quien racionalizó el ensalmo y le convirtió en la metáfora esencial del diálogo socrático como phármakon que cura las enfermedades del alma. Y hasta el mismo Galeno se hará eco de esta larga tradición de la palabra curativa que nació con los griegos y se mantuvo vigente en la medicina romana. Al menos, así lo asegura Laín Entralgo, al decir que

hasta el divino Galeno, que creía que las epódai no eran nada, descubrió al cabo del tiempo y de una larga experiencia que tenían una gran virtud. Escúchale en sus propias palabras en el tratado que compuso 'Sobre la medicina de Homero'. Dice así: 'Algunos efectivamente, creen que los ensalmos son cuentos de viejas, como yo mismo creí durante mucho tiempo. Pero a la postre, por sus efectos evidentes, me convencí de que había una dynamis en ellos. Comprobé su utilidad en las picaduras de serpientes, y la no menor que tenían en el caso de aquellos a quienes se les había atravesado un hueso en la garganta que devolvían inmediatamente

13 Píndaro, Píticas, III, 5-8 y 45-53. Laín, P., La curación ..., cit., pp. 49-50.

14 Sófocles, Áyax, 581-582. 
gracias al ensalmo. Son muchos los remedios excelentes para cada caso, y entre ellos las epódai logran su objeto' (II 475 Puschmann). ${ }^{15}$

El efecto medicinal de la palabra que aparece en los cultos religiosos y en los versos de la poesía griega es recuperado por la filosofía, concebida como escucha de la palabra. Esta concepción se inicia con Pitágoras, el cual no sólo enseñaba a aprender por los ojos del alma, sino muy especialmente por los oídos. Una concepción que destaca especialmente en Heráclito, Empédocles, Sócrates y Platón. Filosofar significa no sólo hablar, conversar y dialogar, sino también saber guardar silencio para escuchar y comprender la palabra y la música que nos libera del error y nos hace felices. Porque la comprensión por el oído produce el mismo efecto catártico y liberador que la contemplación visual. La palabra filosófica es, por ello, epodé.

La filosofía es, según los aforismos terapéuticos de Heráclito, una actividad que consiste en escuchar esa palabra que nos hace hombres, es decir, seres racionales, despiertos, que viven en lo común, en la comunidad y en comunicación, por la experiencia compartida. De lo contrario, los hombres son sordos, inexpertos, incomunicados, aislados, en un mundo particular, sin vínculos humanos.

Pero, tal vez se halle en los poéticos versos de Empédocles la culminación de esta palabra capaz de curar el alma de todas sus dolencias, como un ensalmo inspirado que produce una dulce afección. He aquí su emotiva expresión:

Me siguen a miles preguntándome dónde está el camino que lleva a la salud, los unos buscando vaticinios, los otros, atravesados desde hace tiempo por atroces dolores, buscando escuchar la palabra que cura toda enfermedad. ${ }^{16}$

Empédocles transforma su arte de rapsoda en el de médico del alma por la palabra. La filosofía se convierte en cuidado del alma, en el camino que conduce a la salud, por medio de la palabra persuasiva. Abre con ello la senda que lleva a la palabra terapéutica de Sócrates y a la concepción sanadora de la ética de los cínicos, de los cirenaicos y del mismo Epicuro quien considera que «vana es la palabra del filósofo que no cura ninguna enfermedad» ${ }^{17}$ del alma, pues «la filosofía es una actividad que, con palabras y razonamientos, proporciona una vida feliz». ${ }^{18}$

15 Gil, L., Therapeia, cit., pp. 235-236.

16 DK 31 B 112.

17 Epicuro, fr. 221 Usener.

18 Epicuro, fr. 219 Usener. 
La consolidación de la polis en el siglo de Pericles fue como el descubrimiento de un mundo nuevo en el que la palabra alcanzó su máxima importancia. En esta nueva ciudad democrática la palabra se convierte en el instrumento de comunicación y en el poder más grande para establecer, mediante del debate público en el ágora, la verdad, es decir, el conjunto de normas de convivencia que son compartidas por la mayoría de los ciudadanos. Ahora, de verdad, la palabra es un phármakon, un remedio para las discrepancias y un veneno que establece diferencias e introduce el relativismo de los valores morales y de las normas legales. Ahora, la palabra volverá a establecer el arkhé, no de la physis, sino de la polis.

Son los sofistas, los nuevos educadores del hombre griego, quienes cultivan y desarrollan las artes de la palabra, como la gramática, la retórica y la dialéctica, como principal instrumento de la vida política. El verdadero orador, según Gorgias, será el verdadero político, es decir, el que sea

capaz de persuadir, por medio de las palabras, a los jueces en el tribunal, a los consejeros en el Consejo, al pueblo en la Asamblea y en toda otra reunión en que se trate de asuntos públicos. En efecto, en virtud de este poder, serán tus esclavos el médico y el maestro de gimnasia, e incluso el banquero, se verá que no ha adquirido la riqueza para sí mismo, sino para otro, para ti, que eres capaz de hablar y persuadir a la multitud. ${ }^{19}$

Este arte de la retórica de los sofistas consiste en persuadir mediante la palabra a sus conciudadanos para que logren el éxito en la polis. Pero su palabra persuasiva, que venden a cambio de dinero, como un phármakon, es, a juicio de Sócrates, una medicina con efectos secundarios terribles, pues es una «mercancía de la que se nutre el alma», ${ }^{20}$ y es preciso tener mucho cuidado, pues los alimentos en malas condiciones se llevan en una vasija y pueden desecharse sin daño para el cuerpo, pero las enseñanzas dañinas perjudican el alma, que ya no puede librarse de ellas.

Gorgias concibe la palabra como un arma de combate, como una lanza o una flecha que se arroja sobre el enemigo cuando está desprevenido, con sus escudos bajados, para lograr con ello la victoria en la discusión y persuadir al adversario, haciéndole cambiar de opinión. Tal vez el himno al logos de su Encomio de Helena sea el texto más sublime sobre este poder de las palabras. En él afirma Gorgias que:

La palabra es un poderoso soberano que con un cuerpo pequeñísimo y completamente invisible, lleva a cabo obras sumamente divinas. Puede, por ejemplo,

19 Platón, Gorgias, 452 d.

20 Ib. $313 \mathrm{c}$. 
acabar con el miedo, desterrar la aflicción, producir la alegría o intensificar la compasión. ${ }^{21}$

Lo mismo que Helena, según la leyenda poética transmitida en la oralidad de los aedos, fue capaz de seducir, gracias a su irresistible encanto, a muchos pretendientes, así también la palabra es un ser diminuto, pero divino, capaz de realizar los mismos prodigios que los dioses. Sus efectos los produce en el alma del que aprende, dejando en ella importantes secuelas. El mismo Gorgias, siguiendo a su maestro Córax, define la retórica como «artesana (demiourgós) de la persuasión». ${ }^{22}$ Una persuasión que, según la refutación de Sócrates, «que da lugar a la creencia, pero no a la enseñanza sobre lo justo y lo injusto». ${ }^{23}$ De ahí que la palabra persuasiva de Gorgias sea un malvado demiurgo, que consigue doblegar la resistencia del oyente y lleva su alma por el camino previamente elegido por el maestro de la retórica.

Y, lo mismo que Helena fue persuadida por la palabra seductora, encantadora, irresistible de Paris, abandonando Grecia y provocando la guerra de Troya, así también la palabra encantadora del sofista, la epodé, es capaz de seducir el alma del oyente haciéndole creer que las cosas son tal como las hace aparecer la opinión del que enseña o tal como dice la opinión de la mayoría, haya indagado o no la verdad. Dice así Gorgias:

La misma proporción hay entre el poder de la palabra respecto a la disposición del alma que entre el poder de los medicamentos respecto al estado del cuerpo. Así como unos fármacos expulsan del cuerpo unos humores y otros distintos, y como unos eliminan la enfermedad y otros la vida, así también unas palabras producen tristeza, otras placer, otras temor, otras infunden coraje en los oyentes, otras mediante una maligna persuasión envenenan y engañan al alma. ${ }^{24}$

Esta concepción de la palabra como phármakon recoge toda la tradición de la oralidad homérica, así como la virtualidad y eficacia de las palabras de poetas, legisladores y filósofos anteriores. La palabra es un verdadero phármakon, capaz de suprimir el dolor y provocar el placer, como los dulces ensalmos de la medicina arcaica y la logoterapia de poetas y creadores de mitos sobre el arkhé del cosmos. Es como la palabra encantadora de la tragedia, que mediante el engaño y la ficción de sus héroes míticos purifica al alma del temor y de la compasión, según la conocida interpretación aristotélica. Es, en fin, una palabra que puede privar de la vida y producir la guerra y la muerte,

21 Gorgias, Encomio de Helena, 8.

22 Platón, Gorgias, 453 a.

$23 \mathrm{Ib} .455 \mathrm{a}$.

24 Gorgias, Encomio de Helena, 14. 
como la palabra persuasiva de Paris que arrastra a Helena a Troya, pues, si hay algo que destaca en la retórica de Gorgias, a juicio de Platón, es esa concepción beligerante y violenta de la palabra como arma de combate, que aprovecha el momento oportuno, kairós, en que las defensas de los enemigos están bajadas, como escudos tirados en el campo de batalla, para lanzar el dardo letal de la palabra produciendo el dolor y la muerte.

Es una palabra que se proclama verdadera, pero no busca la persuasión pacífica, no pretende convencer con dulces ensalmos, sino vencer en el combate dialéctico. Pero, vencer no es convencer. Este phármakon de la palabra de los sofistas es más veneno que medicina y, por ello, era preciso buscar un antídoto que neutralizara sus efectos perniciosos en el alma. Y ése será el efecto de la palabra socrática.

La palabra encantadora de Gorgias, más que medicina es una dulce enfermedad, pues conmueve y apasiona al alma, engendrando en ella una opinión (dóxa), pero no la verdad (alétheia). Sócrates se enfrenta a esta concepción de la retórica, afirmando que la retórica no es un verdadero saber medicinal y curativo, sino un arte de adulación que convierte al orador en alguien más persuasivo que el médico sólo ante los niños y la multitud que carece de sensatez. Así la retórica es una técnica o práctica culinaria, pero no una ciencia (epistéme), pues busca el placer del que escucha, no su bien. He aquí las palabras de Sócrates:

La culinaria se introduce en la medicina y finge conocer los alimentos más convenientes para el cuerpo, de manera que si, ante niños u hombres tan insensatos como niños, un cocinero y un médico tuvieran que someter a juicio quién de los dos conoce mejor los alimentos beneficiosos y nocivos, el médico moriría de hambre. A esto lo llamo adulación... porque pone su punto de mira en el placer sin el bien; digo que no es arte, sino práctica, porque no tiene ningún fundamento por el que ofrecer las cosas que ofrece ni sabe cuál es su naturaleza, de modo que no puede decir la causa de cada una de ellas. ${ }^{25}$

Frente a este arte del engaño que produce el phármakon de Gorgias, Sócrates ofrece la palabra curativa de su dialéctica, un logos propio del médico que conoce la naturaleza (physis) del alma del paciente y los efectos beneficiosos del medicamente adecuado a la verdad. Su palabra es una verdadera medicina del alma, un phármakon que produce la salud del alma.

Su psicoterapia o logoterapia es su verdadera vocación, tal como lo exige la exacta interpretación del oráculo de Delfos, cuya enigmática prescripción del conocimiento de uno mismo, le incita a realizar una profunda introspección para conocer su propio logos y un diálogo constante con los demás ciudadanos para incitarles a ese mismo cuidado del alma.

25 Platón, Gorgias, 464 b-465 e. 
El propio Sócrates da testimonio de esta tarea personal e interpersonal impuesta por el oráculo, la palabra inspirada del dios Apolo, el dios de la luz, del conocimiento y de la medicina del alma. Como leemos en la Apología, él habla con todos los atenienses y les incita a buscar, no las riquezas, ni el éxito o la fama, sino una vida reflexiva, saludable, que sólo se alcanza mediante el diálogo y la palabra compartida, como phármakon que introduce en el alma la salud y la armonía y que construye la concordia entre todos los ciudadanos. Él no busca el principio de la physis, sino el principio del hombre, para hacer un certero diagnóstico del estado de salud de su alma y procurarle los medicamentos adecuados. Es, como ya propuso Heráclito, la búsqueda interminable del logos escondido en el alma, que es el oro que ha de preferirse a las mercancías que ofrecen los sofistas, que no son sino traficantes y vendedores de sucedáneos para curar el alma.

Sócrates establece una psicoterapia: primero, el reconocimiento de la ignorancia sobre la naturaleza y, en segundo lugar, conocerse a sí mismo y cuidar de su salud. Como dice el mismo Sócrates:

Conociéndonos, también podremos conocer con más facilidad la forma de cuidar de nosotros mismos, mientras que si no nos conocemos no podríamos hacerlo. ${ }^{26}$

Sócrates es un médico singular. Primero, hace su propio diagnóstico y, luego, se aplica la medicina curativa, antes de recomendarla a los demás. Y, una vez que ha comprobado el efecto beneficioso de ella, enseña a los demás a tomarla en la dosis adecuada y en el momento oportuno.

En efecto, las dos grandes metáforas de su filosofía son la medicina y la música. En realidad, podría decirse que el diálogo socrático es medicina, porque es música. Es decir, es una palabra encantadora, como la de los oráculos inspirados y la de los dulces ensalmos, tal como lo expresa Menón:

Ahora, Sócrates, me estás hechizando y embrujando y encantando por completo, con lo que estoy ya lleno de confusión. ${ }^{27}$

Y también Alcibíades siente en su interior la música inspirada de las palabras socráticas, cuando dice:

¿Que no eres flautista? Por supuesto, y mucho más extraordinario que Marsias. Este, en efecto, encantaba a los hombres mediante instrumentos con el poder de su boca... Mas tú te diferencias de él sólo en que sin instrumentos, con tus meras

26 Platón, Alcibiades I, 129 a.

27 Platón, Menón, 80 a. 
palabras haces lo mismo... Cuando le escucho, mi corazón palpita mucho más que el de los poseídos por la música de los coribantes. ${ }^{28}$

Más aún, el último día de su vida, mirando hacia atrás, el mismo Sócrates interpreta que su diálogo permanente ha sido, como la filosofía, una sinfonía musical, que no ha pretendido sino introducir la armonía de la areté en el alma de sus interlocutores, pues la filosofía es la más alta música, que no se halla sólo en las esferas celestes, sino en el alma humana. Así lo afirma comentando el sueño que le ha perseguido toda su vida, animándole a ejercer como músico. Así lo dice:

¡Sócrates, haz música y aplícate a ello! Y yo, en mi vida pasada, creía que el sueño me exhortaba y animaba a lo que precisamente yo hacía, como los que animan a los corredores, y a mí también el sueño me animaba a eso que yo practicaba, hacer música, en la convicción de que la filosofía era la más alta música. ${ }^{29}$

La filosofía socrática es medicina, justamente porque es música. Es una palabra encantadora que produce salud y armonía en el alma como los ensalmos de los poetas y de los adivinos. Él es un médico que cura al hombre entero. Es un cuidador de los ciudadanos y, por medio de ensalmos y dulces palabras, invita a concebir y dar a luz la verdad, cuida el alma de su interlocutor para engendrar en ella la excelencia. Hay un precioso texto en el que Sócrates describe este arte de la psicoterapia. Dice así:

Es del alma de donde arrancan todos los males y los bienes para el cuerpo y para todo el hombre; como le pasa a la cabeza con los ojos. Así pues, es el alma lo primero que hay que cuidar al máximo, si es que se quiere tener bien la cabeza y todo el cuerpo. El alma, venerable amigo, se trata con ciertos ensalmos y estos ensalmos son los buenos discursos y de tales buenos discursos nace en ella la sensatez. Y, una vez que ha nacido y permanece, se puede proporcionar salud a la cabeza y a todo el cuerpo. ${ }^{30}$

Una psicoterapia que llega a su momento culminante en las últimas palabras que pronuncia Sócrates y que sintetizan esta visión de la vida como una enfermedad mortal del alma, encerrada en la cárcel del cuerpo. No puede haber mayor expresión de humor y de ironía que el último deseo socrático de sacrificar un gallo al dios que cura las enfermedades, cuando el veneno está ya haciendo efecto y la muerte está próxima. Pero tiene pleno sentido si la vida se entiende sólo como una enfermedad mortal, que paradójicamente sólo la muerte

28 Platón, Banquete, 215 b.

29 Platón, Fedón, 60 e - 61 a.

30 Platón, Cármides, 156 e - 157 a. 
puede curar. Y, quien ha pasado el último día de su vida conversando sobre la filosofía como preparación para la muerte, con toda coherencia se siente feliz y dichoso, porque por fin se ha curado de la inevitable enfermedad mortal que el hombre contrae por nacer: la vida. La filosofía es preparación para la muerte, es aprender a vivir separado del cuerpo, como si el hombre fuera simplemente el alma, que es seguramente la principal aportación de Sócrates a la filosofía occidental. El famoso pasaje es el siguiente:

$<$ Sócrates $>$ nos dijo, y fue lo último que habló:

- Critón, le debemos un gallo a Asclepio. Así que págaselo y no lo descuides.

-Así se hará -dijo Critón-. Mira si quieres algo más.

Pero a esta pregunta ya no respondió, sino que al poco rato tuvo un estremecimiento y el hombre le descubrió, y él tenía rígida la mirada. Al verlo, Critón le cerró la boca y los ojos. ${ }^{31}$

Pero Sócrates es algo más que un médico particular, es el verdadero médico de la polis. Él, según la propuesta de Platón, debería haber sido el gobernante de la ciudad que le condenó a muerte. Esa condena demuestra que la polis está enferma, por ello necesitan una educación adecuada todos sus ciudadanos, $\mathrm{y}$, sobre todo, necesitan ser guiados por una palabra que les saque de las sombras de la apariencia e introduzca en sus almas la verdad y la justicia. Esa es la tarea socrática, cuyo diálogo es el deber que el dios le ha impuesto al servicio de la ciudad. La filosofía es cuidado y curación del alma por medio del phármakon de la palabra encantadora, del ensalmo socrático:

Voy por todas partes - dice a los jueces - sin hacer otra cosa que intentar persuadiros, a jóvenes y viejos, a no tener cuidado ni de los cuerpos ni de los bienes antes que del alma, ni con tanto afán, a fin de que ésta sea lo mejor posible. ${ }^{32}$

Sólo los filósofos, los médicos del alma, como Sócrates, han de ser los verdaderos políticos, pues la ciudad está enferma y necesita un cuidado especial. Son conocidas aquellas palabras en que Platón asegura que

no se curarán las enfermedades de la polis, ni de los hombres todos, a no ser que sean gobernados por auténticos filósofos. ${ }^{33}$

Así que, según Sócrates, la filosofía es psicoterapia y logoterapia, es decir, cuidado del alma mediante la palabra, porque el logos es el antídoto contra el

31 Platón, Fedón, 118 a - b.

32 Platón, Apología de Sócrates, $30 \mathrm{a}-\mathrm{b}$.

33 Platón, República, V, 473 d. 
desorden, la arbitrariedad y la injusticia en la vida humana, a la vez que es el phármakon capaz de establecer, mediante el autoconocimiento y la búsqueda interior, el arkhé que ha de guiar al hombre y a la polis.

Esa es la vocación de Sócrates, la de director de la orquesta sinfónica de la polis, que mediante la meloterapia del logos logra la armonía y la concordia entre los ciudadanos, la de médico, cuya palabra es el phármakon que cura la injusticia, supremo mal del hombre y de la ciudad.

Hipócrates, probable discípulo de Gorgias, es el contrapunto de esta medicina del alma de Sócrates. Él circunscribe la enfermedad al cuerpo, criticando la superstición y la atribución de la enfermedad a potencias divinas y posesiones demoníacas. La enfermedad es un desorden natural del cuerpo, en el que se rompe el equilibrio (isonomía) de los cuatro humores y se produce el predominio (monarchía) de uno de ellos sobre los demás.

Sin embargo, la palabra también es un instrumento terapéutico en la medicina hipocrática. No sólo porque el médico ha de interrogar al paciente para conocer su estado interior, sino porque su palabra ha de establecer el diagnóstico y sobre todo el pronóstico que conducirá a la curación. Pues las causas de la enfermedad se hallan en la misma naturaleza del paciente, a la que hay que conocer y ayudar a que vuelva a encontrar el equilibrio perdido.

Así que la medicina hipocrática adopta el nombre de physiología, porque su base se halla en un certero conocimiento de la naturaleza y se convierte en un verdadero arte de curar (tékhne iatriké) el desorden corporal durante cinco siglos. Pero la palabra del médico que conforta y robustece el ánimo del enfermo para que emprenda, mediante la dieta y el ejercicio, un tratamiento natural de su enfermedad, es también una psicoterapia natural, un ensalmo que se ha desprendido de los elementos mágicos y religiosos que tuvo desde Homero.

Platón, en cambio, propone literalmente «ir más allá de Hipócrates», ${ }^{34}$ no limitándose a conocer la naturaleza del cuerpo, sino también la del alma, pues para que la curación sea completa se ha de atender al hombre entero. Y, comparando el arte de la palabra con la medicina de Hipócrates, afirma que el verdadero orador, Sócrates, el filósofo que cura por la palabra, debe guiar el alma hacia su excelencia, por medio de las palabras adecuadas. Como el buen agricultor, ha de sembrar en el jardín del alma la verdad y la belleza de las ideas que son su genuino alimento. Pero como no resultan adecuados ni los mitos homéricos, ni la retórica de los sofistas, pues no ofrecen modelos dignos de imitación, es preciso crear nuevos mitos y ejercitar el diálogo para adquirir una vida saludable. El diálogo es el ejercicio de la mente y los mitos son la dieta adecuada del alma. 
Así, el arte de la retórica, la filosofía socrática, ha de ser como el arte de la medicina hipocrática, un arte que conoce la verdadera naturaleza del alma y de los medicamentos, que son los discursos, de manera que, siguiendo el método de Gorgias y de Hipócrates, el filósofo ha de aplicar a cada tipo de alma el discurso o fármaco adecuado, en el tiempo oportuno y en la dosis exacta. Por lo tanto, Platón convierte al médico hipocrático en filósofo, en médico del alma, que practica la logoterapia socrática, que bien puede llamarse el arte de la mayéutica, el arte de engendrar en al alma del que aprende bellos y hermosos discursos que dan felicidad a quien los cultiva.

Esta mayéutica medicinal de Sócrates, capaz de cambiar el rumbo de la vida del propio individuo, es la herencia que recibieron también los filósofos del helenismo, que se sintieron aprendices de esa medicina filosófica, como lo muestran las palabras de Epicuro, que son la mejor expresión de la analogía entre medicina y filosofía. Con ellas quiero terminar:

Nadie por ser joven dude en filosofar ni por ser viejo de filosofar se hastíe. Pues nadie es joven o viejo para la salud del alma. El que dice que aún no es edad o que ya pasó la edad de filosofar es como el que dice que aún no ha llegado o que ya pasó el tiempo oportuno para la felicidad. De modo que deben filosofar tanto el joven como el viejo. Éste para que, aunque viejo, rejuvenezca en bienes por el recuerdo gozoso del pasado, aquél para que sea joven y viejo a un tiempo por su serenidad ante el futuro. Necesario es, pues, meditar sobre lo que procura la felicidad, porque cuando está presente todo lo tenemos y, cuando nos falta, todo lo hacemos por poseerla. ${ }^{35}$

Los filósofos, pues, no son más que médicos del alma, que aplican un único medicamento: las palabras. El medicamento primero de la medicina griega y, a juicio de Freud, el medicamento esencial para curar los traumas del alma, pues éstos se liberan y disuelven, como la herida de Ulises, cuando se hacen presentes en la palabra del enfermo y, tras la escucha atenta, reciben una respuesta consoladora y esperanzada del médico, que cura también con dulces ensalmos, pues a él se acercan todos, como si fuera el mago y curandero Empédocles, buscando escuchar la palabra que cura toda enfermedad.

Pablo García Castillo ha sido durante cuarenta años profesor, director de Departamento y Decano de la Facultad de Filosofía de la Universidad de Salamanca. Actualmente es profesor jubilado.

35 Epicuro, Carta a Meneceo, en Diógenes Laercio X, 122. 
Líneas de investigación:

La historia de la filosofía antigua y su recepción en la época contemporánea.

Publicaciones recientes:

García Peña, I., García Castillo, P., Materiales didácticos de historia de la filosofía antigua, Salamanca, Ediciones Universidad de Salamanca, 2018.

García Peña, I, García Castillo, P. Unamuno: Filosofía Lógica, Madrid, Tecnos, 2016.

Email:

castillo@usal.es 
